\title{
Evaluation of the Role of Vitamin D in Chronic Kidney Disease, Dialysis Patients and Its Impact on Cardio Vascular Mortality
}

\begin{abstract}
Mohamed E. Ibrahim ${ }^{\text {a }}$, Kamal M. Okasha ${ }^{\text {a }}$, Ashraf Talaat ${ }^{\text {b }}$, Amany G. Abd El-Aziz ${ }^{\text {a }}$, Ahmed E. Mansour $^{a}$
\end{abstract}

\begin{abstract}
a
Department of Internal Medicine and Nephrology, Faculty of Medicine, Banha University, Egypt. b Department of Internal Medicine, Dean of Damietta Faculty of Medicine, Damietta University, Egypt.
\end{abstract}

Correspondence to: Amany G. Abd El-Aziz, Department of Internal Medicine and Nephrology, Faculty of Medicine, Banha University, Egypt.

Email:

amanygamal2021@yahoo.com

Received: 10 April 2021

Accepted: 9 September 2021

\section{Abstract}

Background: Patients with chronic kidney disease are frequently suffering from the deficiency of 1,25-dihydroxyvitamin D3 (calcitriol). This study aimed to evaluate the role of vitamin D deficiency in chronic kidney disease patients, with and without dialysis and its impact on cardio vascular morbidity If fetal or not fatal. Methods: The study was carried on 100 cases and divided into three groups: Group A: 25 healthy cases (control group), Group B: 50 patients with known chronic kidney disease under conservative treatment and Group C: 25 patients with chronic kidney diseases under hemodialysis. Results: Group A (control) included 10 males and 15 females, their mean age was $42.56 \pm 3.1$ years, group B (CKD) included 27 males and 23 females, their mean age was 41.6 \pm 2.5 years, group C (CKD+ dialysis) included 12 males and 13 females, their mean age was $43.3 \pm 2$ years. Vitamin $D$ was statistically higher in group A (36 \pm 7.4$)$ than group B (17 \pm 2.5$)$, and group $\mathrm{C}(11.4 \pm 1.5), \mathrm{p}<0.001$. And between group $\mathrm{B} \& \mathrm{C}, \mathrm{p}<0.001$. The group with normal ECG had statistically higher levels of vitamin D $($ mean $=24.5 \pm 10.8)$ compared to the group with abnormal ECG $($ mean= $13.9 \pm 4.1)$, $\mathrm{p}<0.001$. Eight patients of group B (16\%) died during the study period, On comparison between alive and died patients regarding the clinical data; vit D was statistically higher in alive group, $\mathrm{p}=0.04$. Conclusion; High prevalence of vit $\mathrm{D}$ deficiency in CKD patients, and showed a significant association between 25-OH vitamin D levels and major ECG abnormalities and Echo.

Keywords: Vitamin D; kidney; dialysis; cardiovascular; mortality 


\section{Introduction}

Vitamin D is an essential steroid hormone with effects extending beyond its classical role in bone-mineral disease. Recently, the importance of vitamin D in the kidneys, cardiovascular disease, immune system, and cancer has been recognized. With these new roles being studied, there is growing interest in the therapeutic potential of vitamin D (1).

Vitamin D deficiency has been defined as 25(OH)D levels $<20 \mathrm{ng} / \mathrm{ml}(50 \mathrm{nmol} / \mathrm{l})$ and adequacy as levels $\geq 30 \mathrm{ng} / \mathrm{ml}(75 \mathrm{nmol} / \mathrm{l})$. Serum concentrations of $25(\mathrm{OH}) \mathrm{D}$ above $50 \mathrm{ng} / \mathrm{ml}$ (125 nmol/l) should be prevented, since risks have been identified for some outcomes . Vitamin D deficiency is highly prevalent in the general population, and prevalence varies by geographical location, diet, and comorbidities (2).

Chronic kidney disease (CKD) is a major public health problem worldwide, and its main consequences include loss of renal function leading to end-stage renal disease (ESRD), increased risk of cardiovascular disease (CVD), significant increase in morbidity and mortality, and a decrease in health-related quality of life .Indeed, the risk of CKD increases with age and elderly patients are overrepresented in the dialysis population. However, there seems to be a complex relationship between aging and $\mathrm{CKD}$, as geriatric complications are highly detectable in younger patients with ESRD . This has led to the hypothesis of a premature biological aging process of different organ systems associated with CKD (3).

In patients suffering from chronic kidney disease (CKD), the prevalence of cardiovascular disease is much more common than in the general population. The role of vitamin D deficiency had been underestimated until a significant association was found between vitamin D therapy and survival benefit in haemodialysis patients. Vitamin

D deficiency is present even in the early stages of chronic kidney disease. The results of experimental studies have revealed the relationship between vitamin D deficiency and impairment of cardiac contractile function, higher cardiac mass and increased myocardial collagen content. Experimental models propose that intermediate end points for the relationship between vitamin D deficiency and higher risk of cardiovascular disease comprise diminished left ventricular hypertrophy (LVH), enhanced left ventricular diastolic function, and decreased frequency of heart failure. (4). 
Multiple observational studies have demonstrated an association between the use of active vitamin D therapy in patients on dialysis and with CKD and improved survival. However, there are also many studies indicating important adverse effects of such treatment. Therefore, large randomized trials are required to analyze whether supplementation of vitamin D may affect outcomes and whether it is safe to be used in CKD patients (4). Also abnormalities of calcium, phosphorus, vitamin D, and parathyroid hormone (PTH) are associated with the occurrence of cardiovascular disease. (5)

Some of them also indicate a relationship between vitamin $\mathrm{D}$ deficiency and hypertension, insulin resistance, diabetes, and dyslipidaemia. Research has linked inadequate vitamin D status to nonskeletal major chronic diseases, especially cardiovascular diseases (6).

Existing data from laboratory studies, epidemiologic and experimental research and prevention trials, suggest that vitamin D reduces the risk of cardiovascular disease, and a large, randomized, primary prevention trial, with adequate dosing, combining cholecalciferol and omega-3 fatty acids, is ongoing: the VITAL study. Poor vitamin D status was associated with cardiovascular and overall mortality, despite unconvincing results of vitamin D supplementation on mortality (7).

This study aimed to evaluate the role of vitamin $\mathrm{D}$ deficiency in chronic kidney disease patients with or without hemodialysis and its impact on cardio vascular morbidity and mortality

\section{Patients and methods}

This case-control prospective study, was conducted in police hospital (Agouza and Tanta). During the period from June 2019September 2020.

The study was carried on 100 cases and divided into three groups:

- Group A: 25 healthy cases serving as control group.

- Group B: 50 patients with known chronic kidney disease under conservative treatment.

- Group C: 25 patients with chronic kidney diseases under hemodialysis.

\section{Inclusion criteria:}

- Age $>18$ years old.

- Patients who have chronic kidney disease under conservative treatment or hemodialysis. 


\section{Exclusion criteria:}

- Patients with self-reported angina

- Patients with a past history of congestive heart failure, myocardial infarction, and stroke

- Patients with uncontrolled DM, or hypertension.

- Patients receiving steroid therapy.

This study was approved by the ethical committee of Benha Faculty of medicine. Informed consent was taken from all Patients for the study participation. All patients in this study was subjected to Complete history taking, physical Examination, 12 Lead ECG, and conventional, tissue Doppler and two dimensional speckle tracking echocardiography, and laboratory investigations: at start then at 3,6, and 9 months, including:

- Serum concentration of $25 \mathrm{OH}$ vit. D, with follow up on supplement.

- $\mathrm{CBC}$

- Serum creatinine

- Serum urea

- Serum albumin

- Parathyroid hormone level

- Serum electrolyte (total, ionized ca, $\mathrm{k}$ ,p)

- Lipid profile

- Thyroid function tests (free T3, free T4, TSH)

- $\mathrm{Hb} \mathrm{A1c}$

\section{Statistical analysis}

The data were coded, entered and processed on computer using SPSS (version 24). The results were represented in tabular and diagrammatic forms then interpreted. Mean, standard deviation, range, frequency, and percentage were use as descriptive statistics. The following tests were done: Student's ttest: It is a single test used to collectively indicate the presence of any significant difference between two groups for a normally distributed quantitative variable. One a way ANOVA (F test): A one-way analysis of variance (ANOVA) is a single test used to collectively indicate the presence of any significant difference between several groups for a normally distributed quantitative variable. Spearman Correlation analysis: It is used to show strength and direction of association between one quantitative variable and ordinal qualitative variable. The accepted level of significance was 0.05 .

\section{Results}

Group A (control) included 10 males and 15 females, their mean age was $42.56 \pm 3.1$ years, group B (CKD) included 27 males and 23 females, their mean age was $41.6 \pm 2.5$ years, group C (CKD+ dialysis) included 12 males and 13 females, their 
mean age was $43.3 \pm 2$ years. There was no statistical difference between groups regarding gender, or age. Table 1, lab. Investigations in table 2

Vitamin D was statistically higher in group A (36 \pm 7.4$)$ than group B (17 \pm 2.5$)$, and group C (11.4 \pm 1.5$), \mathrm{p}<0.001$. And between group $\mathrm{B} \& \mathrm{C}, \mathrm{p}<0.001$. Figure 1

One patient of group A (4\%) had abnormal ECG, 13 patients (26\%) of group B had abnormal ECG, while $100 \%$ of group C had abnormal ECG, there was statistical difference between groups regarding ECG $(p<0.001)$. the group with normal ECG had statistically higher levels of vitamin D $($ mean $=24.5 \pm 10.8)$ compared to the group with abnormal ECG (mean= 13.9 \pm 4.1$)$, $\mathrm{p}<0.001$. figure 2

Regarding the Echocardiography; there was statistical difference between groups regarding to some determinants of $\mathrm{LV}$ diastolic and systolic functions; patients in group A had statistically lower average $\mathrm{e}^{\prime}$ than group B\&C, and had statistically longer IVRT, and significantly higher E/e'. This is suggestive of a better diastolic function. There was no significant difference between both groups regarding average a', E wave velocity, A wave velocity, E-DcT, LAV, $\mathrm{E} / \mathrm{A}$, and $\mathrm{e}^{\prime} / \mathrm{a}^{\prime}$. Also patients in group $\mathrm{A}$ had a significantly lower ESV, higher EF, lower ESD, lower IVS thickness, lower PW thickness, lower mean LV wall thickness, and lower LV mass compared with group $\mathrm{B} \& \mathrm{C}$, while average $\mathrm{s}^{\prime}$, and EDV were not different. This is suggestive of a better systolic function. Moreover patients in group B had significantly lower ESV, lower IVS thickness, and lower mean LV wall thickness when compared with group C. table 3

There was a significant negative correlation between vit D and (Mean e', Mean s', ESV, ESD, IVS thickness, PW thickness, Mean LV thickness, and LV mass), and there was a significant positive correlation between vit $\mathrm{D}$ and (IVRT, E/e', and EF), while there was no significant correlation between vit $\mathrm{D}$ and (Mean a', mean E, mean A, E-DcT, LAV, $\mathrm{E} / \mathrm{A}$, and $\left.\mathrm{e}^{\prime} / \mathrm{a}^{\prime}\right)$. Table 4

Eight patients of group B (16\%) died during the study period, compared to 3 patients (12\%) of group C, there was no statistical difference between groups regarding status of death. there was no statistical difference between groups regarding levels of $\mathrm{Hb}, \mathrm{Plt}$, TLC, Urea, creatinine, total $\mathrm{Ca}$, ionized $\mathrm{Ca}$, Po4, and potassium. While there was statistical difference between group regarding PTH (statistically higher in alive 
group, $\mathrm{p}=0.025$ ) and vit $\mathrm{D}$ was statistically higher in alive group, $p=0.04$. Figure 3

There was no significant correlation between vitamin $\mathrm{D}$ and age or sex, while there was significant positive correlation between vitamin $\mathrm{D}$ and $(\mathrm{Hb}, \mathrm{Plt}$, and total $\mathrm{Ca}$ ), and there was significant negative correlation between vitamin D and (urea, creatinine, PTH, ionized $\mathrm{Ca}, \mathrm{Po} 4$, and $\mathrm{K}$ ).

Table 5
Vitamin D could predict ECG abnormality with $\mathrm{AUC}=0.859$. And at cutoff value of 17.650 , the sensitivity was $76.9 \%$, and specificity was $73.1 \%$. vitamin D could predict mortality with $\mathrm{AUC}=0.682$. And at cutoff value of 17.650 , the sensitivity was $81.8 \%$, and specificity was $51.7 \%$. Figure 4 , 5.

Table 1: Demographic data of the studied groups

\begin{tabular}{llcccccccc}
\hline & & \multicolumn{2}{c}{ Group A } & \multicolumn{2}{c}{ Group B } & \multicolumn{2}{c}{ Group C } & Test & p-value \\
& & $\mathbf{N}=\mathbf{2 5}$ & $\mathbf{\%}$ & $\mathbf{N}=\mathbf{5 0}$ & $\mathbf{\%}$ & $\mathbf{N}=\mathbf{2 5}$ & $\mathbf{\%}$ & & \\
\hline Gender & Male & 10 & $40.0 \%$ & 27 & $54.0 \%$ & 12 & $48.0 \%$ & $\mathrm{X}^{2}=1.32$ & $\mathrm{P}=0.517$ \\
& Female & 15 & $60.0 \%$ & 23 & $46.0 \%$ & 13 & $52.0 \%$ & & \\
Age/ year & Mean \pm SD & $42.56 \pm 3.1$ & $41.6 \pm 2.5$ & $43.3 \pm 2$ & $\mathrm{~F}=1.9$ & $\mathrm{P}=0.152$ \\
& Range & $35-50$ & $37-46$ & $40-48$ & & \\
\hline
\end{tabular}

$\mathrm{X}^{2}$ : chi-square test, $\mathrm{F}$ : one way ANOVA

Table 2: Comparison between the groups regarding their laboratory investigations

\begin{tabular}{|c|c|c|c|c|c|c|c|c|}
\hline & \multicolumn{2}{|c|}{ Group A } & \multicolumn{2}{|c|}{ Group B } & \multicolumn{2}{|c|}{ Group C } & \multirow[t]{2}{*}{ Test } & \multirow[t]{2}{*}{$P$ value } \\
\hline & Mean \pm SD & Range & Mean \pm SD & Range & Mean \pm SD & Range & & \\
\hline Hb g/dl & $13.7 \pm 1.0$ & $12.3-15.8$ & $10.5 \pm 1$ & $8.8-12.1$ & $9.8 \pm 1.4$ & $7.6-10.1$ & $\mathrm{~F}=90.8$ & $\mathrm{P}<0.001 * *$ \\
\hline PIt $10^{3} / l$ & $291 \pm 40$ & 233-349 & $168 \pm 36$ & $110-224$ & $120 \pm 30$ & $73-175$ & $\begin{array}{c}t=2.6 \\
F=157.9 \\
t=5.6\end{array}$ & $\begin{array}{l}\mathrm{P}=0.023^{*} \\
\mathrm{P}<0.001 * * \\
\mathrm{P}<0.001 * *\end{array}$ \\
\hline TLC $10^{3} / 1$ & $7.2 \pm 2.3$ & $3-12$ & $5.2 \pm 2.9$ & $2-11$ & $8.3 \pm 3.1$ & $1.5-10$ & $\begin{array}{c}\mathrm{F}=80.5 \\
\mathrm{t}=2.6\end{array}$ & $\begin{array}{c}\mathrm{P}<0.001 * * \\
\mathrm{P}=0.02 *\end{array}$ \\
\hline Urea & $13.9 \pm 3.6$ & 7.8-19.7 & $92.8 \pm 5.4$ & $35-132.8$ & $128.9 \pm 6.5$ & $\begin{array}{l}79.4- \\
150.1\end{array}$ & $\begin{array}{c}\mathrm{F}=1264 \\
\mathrm{t}=31.9\end{array}$ & $\begin{array}{l}\mathrm{P}<0.001 * * \\
\mathrm{P}<0.001 * *\end{array}$ \\
\hline Creatinine & $0.7 \pm 0.1$ & $0.5-0.8$ & $4.6 \pm 0.1$ & $2.3-2.5$ & $9.3 \pm 2.9$ & $1.8-5.9$ & $\begin{array}{c}F=423.3 \\
t=17.3\end{array}$ & $\begin{array}{l}\mathrm{P}<0.001 * * \\
\mathrm{P}<0.001 * *\end{array}$ \\
\hline Ca total & $9.5 \pm 0.5$ & $8.8-10.4$ & $8.4 \pm 1$ & $6.8-10.1$ & $8 \pm 0.9$ & $6.7-9.3$ & $\begin{array}{c}\mathrm{F}=22.3 \\
\mathrm{t}=2.1\end{array}$ & $\begin{array}{c}\mathrm{P}<0.001^{* *} \\
\mathrm{P}=0.035^{*}\end{array}$ \\
\hline Po4 & $4 \pm 0.3$ & 3.4- 4.5 & $4.8 \pm 0.7$ & $3.6-5.8$ & $5.3 \pm 1.1$ & $3.7-5.8$ & $\begin{array}{c}\mathrm{F}=17.2 \\
\mathrm{t}=1.1\end{array}$ & $\begin{array}{c}\mathrm{P}<0.001 * * \\
\mathrm{P}=0.25\end{array}$ \\
\hline $\mathbf{K}$ & $4.4 \pm 0.5$ & $3.5-5$ & $5.1 \pm 0.73$ & $5.2-6.8$ & $5.2 \pm 0.54$ & $5.2-7.1$ & $\begin{array}{c}\mathrm{F}=145.8 \\
\mathrm{t}=9.1\end{array}$ & $\begin{array}{l}\mathrm{P}<0.001 * * \\
\mathrm{P}<0.001 * *\end{array}$ \\
\hline $\begin{array}{l}\text { PTH } \\
\text { median }\end{array}$ & $83.7 \pm 259$ & $\begin{array}{c}14.3- \\
325\end{array}$ & $355 \pm 117.5$ & $\begin{array}{c}138.1- \\
1422\end{array}$ & $381 \pm 127$ & $\begin{array}{c}338.8- \\
1304\end{array}$ & $\begin{array}{l}F=46.9 \\
t=1.52\end{array}$ & $\begin{array}{c}\mathrm{P}<0.001 * * \\
\mathrm{P}=0.133\end{array}$ \\
\hline vitamin D & $36 \pm 7.4$ & $25.7-47.7$ & $17 \pm 2.5$ & $13.1-21$ & $11.4 \pm 1.5$ & $9-13.9$ & $\begin{array}{c}\mathrm{F}=252.2 \\
\mathrm{t}=10.3\end{array}$ & $\begin{array}{l}\mathrm{P}<0.001 * * \\
\mathrm{P}<0.001 * *\end{array}$ \\
\hline
\end{tabular}


Table 3: Comparison between groups regarding the Echocardiography determinants of LV diastolic and systolic functions

\begin{tabular}{|c|c|c|c|c|c|c|}
\hline & & $\begin{array}{c}\text { Group A } \\
\text { Mean } \pm \text { SD }\end{array}$ & $\begin{array}{c}\text { Group B } \\
\text { Mean } \pm \text { SD }\end{array}$ & $\begin{array}{c}\text { Group C } \\
\text { Mean } \pm \text { SD }\end{array}$ & Test & p-value \\
\hline \multirow{13}{*}{$\begin{array}{l}\text { Diastolic } \\
\text { function }\end{array}$} & Mean $\mathrm{e}^{\prime}(\mathrm{cm} / \mathrm{s})$ & $5.4 \pm 1.7$ & $6.3 \pm 1.8$ & $6.2 \pm 1.6$ & $\mathrm{~F}=5.46$ & $0.033^{*}$ \\
\hline & & & & & $\mathrm{t}=0.09$ & 0.798 \\
\hline & Mean $\mathbf{a}^{\prime}(\mathrm{cm} / \mathrm{s})$ & $6.8 \pm 2.6$ & $7.53 \pm 2.6$ & $7.44 \pm 2.4$ & $\mathrm{~F}=1.02$ & 0.355 \\
\hline & $E(\mathrm{~cm} / \mathrm{s})$ & $89.3 \pm 24$ & $77.7 \pm 21.4$ & $75.9 \pm 21.2$ & $\mathrm{~F}=2.1$ & 0.09 \\
\hline & $\mathrm{A}(\mathbf{c m} / \mathbf{s})$ & $59.6 \pm 27.4$ & $67.6 \pm 29.3$ & $67 \pm 28.5$ & $\mathrm{~F}=1.09$ & 0.361 \\
\hline & E-DcT (ms) & $151.7 \pm 67$ & $164.8 \pm 83.8$ & $165.1 \pm 81$ & $\mathrm{~F}=0.97$ & 0.574 \\
\hline & LAV (ml) & $75.7 \pm 18.1$ & $77.1 \pm 22.5$ & $79 \pm 26$ & $\mathrm{~F}=0.76$ & 0.643 \\
\hline & IVRT (ms) & $116.7 \pm 18$ & $101.3 \pm 21$ & $100.5 \pm 22.1$ & $F=3.98$ & $0.011^{*}$ \\
\hline & & & & & $\mathrm{t}=0.89$ & 0.56 \\
\hline & $\mathbf{E} / \mathbf{A}$ & $1.85 \pm 1.1$ & $1.57 \pm 0.88$ & $1.47 \pm 0.92$ & $\mathrm{~F}=1.4$ & 0.213 \\
\hline & $\mathbf{E} / \mathbf{e}^{\prime}$ & $18.5 \pm 8.4$ & $12.1 \pm 4.22$ & $12.5 \pm 4.17$ & $\mathrm{~F}=6.2$ & $0.002 *$ \\
\hline & & & & & $\mathrm{t}=0.95$ & 0.19 \\
\hline & $\mathbf{e}^{\prime} / \mathbf{a}^{\prime}$ & $0.89 \pm 0.34$ & $0.98 \pm 0.33$ & $0.97 \pm 0.41$ & $\mathrm{~F}=0.93$ & 0.504 \\
\hline \multirow{14}{*}{$\begin{array}{l}\text { Systolic } \\
\text { function }\end{array}$} & Mean s' $(\mathrm{cm} / \mathrm{s})$ & $4.78 \pm 1.45$ & $5.4 \pm 1.33$ & $5.5 \pm 1.21$ & $\mathrm{~F}=1.68$ & 0.127 \\
\hline & EDV (ml) & $150.2 \pm 28.4$ & $178.8 \pm 58$ & $180 \pm 55.9$ & $\mathrm{~F}=2.1$ & 0.058 \\
\hline & ESV (ml) & $96 \pm 20$ & $109.9 \pm 45$ & $119.6 \pm 49.2$ & $\mathrm{~F}=4.1$ & $0.05^{*}$ \\
\hline & & & & & $\mathrm{t}=2.9$ & $0.02 *$ \\
\hline & EF (\%) & $55.8 \pm 7.2$ & $34.2 \pm 8.5$ & $34.1 \pm 8.4$ & $\mathrm{~F}=7.09$ & $<0.001 *$ \\
\hline & & & & & $\mathrm{t}=0.51$ & 0.811 \\
\hline & $\operatorname{ESD}(\mathbf{m m})$ & $45.3 \pm 5.1$ & $50.3 \pm 6.5$ & $49.5 \pm 7.5$ & $\mathrm{~F}=2.13$ & 0.056 \\
\hline & IVS thickness (mm) & $9.3 \pm 1.7$ & $10.9 \pm 2.9$ & $12.7 \pm 3.2$ & $\mathrm{~F}=7.97$ & $<0.001^{*}$ \\
\hline & & & & & $\mathrm{t}=3.9$ & $<0.001^{*}$ \\
\hline & PW thickness (mm) & $9.3 \pm 1.9$ & $12.3 \pm 2.6$ & $13.3 \pm 3$ & $\begin{array}{l}F=8.4 \\
t=1.4\end{array}$ & $\begin{array}{c}<0.001 * \\
0.07\end{array}$ \\
\hline & Mean thickness (mm) & $9.3 \pm 1.8$ & $11.5 \pm 2.4$ & $13 \pm 3$ & $\mathrm{~F}=7.55$ & $<0.001 *$ \\
\hline & & & & & $\mathrm{t}=2.1$ & $0.041 *$ \\
\hline & LV mass (g) & $268 \pm 79$ & $352 \pm 154$ & $372 \pm 195$ & $\mathrm{~F}=5.1$ & $0.05^{*}$ \\
\hline & & & & & $t=0.97$ & 0.12 \\
\hline
\end{tabular}

Table 4: Correlations with echocardiographic determinants of LV diastolic and systolic functions versus vitamin D

\begin{tabular}{|c|c|c|c|}
\hline & & $\mathbf{R}$ & $\mathbf{P}$ \\
\hline \multirow[t]{10}{*}{ Diastolic function } & Mean $\mathrm{e}^{\prime}(\mathrm{cm} / \mathrm{s})$ & -0.554 & $<0.001 *$ \\
\hline & Mean a' $(\mathrm{cm} / \mathrm{s})$ & -0.112 & 0.450 \\
\hline & $\mathbf{E}(\mathbf{c m} / \mathbf{s})$ & 0.081 & 0.582 \\
\hline & $\mathrm{A}(\mathbf{c m} / \mathbf{s})$ & -0.148 & 0.322 \\
\hline & E-DcT (ms) & -0.106 & 0.474 \\
\hline & $\mathbf{L A V}(\mathbf{m l})$ & -0.104 & 0.481 \\
\hline & IVRT (ms) & 0.55 & $<0.001 *$ \\
\hline & $\mathbf{E} / \mathbf{A}$ & 0.158 & 0.290 \\
\hline & $\mathbf{E} / \mathbf{e}^{\prime}$ & 0.63 & $<0.001 *$ \\
\hline & $\mathbf{e}^{\prime} / \mathbf{a}^{\prime}$ & -0.239 & 0.06 \\
\hline \multirow[t]{8}{*}{ Systolic function } & Mean s' $(\mathrm{cm} / \mathrm{s})$ & -0.43 & $<0.001 *$ \\
\hline & $\operatorname{ESV}(\mathrm{ml})$ & -0.41 & $0.001 *$ \\
\hline & $\mathrm{EF}(\%)$ & 0.458 & $0.004 *$ \\
\hline & ESD $(\mathbf{m m})$ & -0.41 & $0.005^{*}$ \\
\hline & IVS thickness (mm) & -0.615 & $<0.001 *$ \\
\hline & PW thickness (mm) & -0.749 & $<0.001 *$ \\
\hline & Mean thickness (mm) & -0.704 & $<0.001 *$ \\
\hline & LV mass (g) & -0.54 & $<0.001 *$ \\
\hline
\end{tabular}

F: one way anova; compare the means of the 3 groups, t: student t-test; compare the means of group B\&C. 
Benha medical journal, vol. 38, issue 3, 2021

Table 5: Correlation between vitamin D and age and other laboratory investigations

\begin{tabular}{lcc}
\hline & Vitamin D & P value \\
\hline Age & r & 0.774 \\
Sex & 0.029 & 0.679 \\
Hb & 0.042 & $<0.001^{* *}$ \\
Plt & $0.710^{* *}$ & $<0.001^{* *}$ \\
Urea & $0.799^{* *}$ & $<0.001^{* *}$ \\
Creatinine & $-0.791^{* *}$ & $<0.001^{* *}$ \\
PTH & $-0.771^{* *}$ & $<0.001^{* *}$ \\
Ca total & $-0.673^{* *}$ & $<0.001^{* *}$ \\
Ca ionized & $0.527^{* *}$ & $<0.001^{* *}$ \\
Po4 & $-.0505^{* *}$ & $<0.001^{* * *}$
\end{tabular}

r: Pearson correlation, PTH: parathyroid hormone, Ca: calcium, Po4: phosphorus, K: potassium, Hb: hemoglobin, Plt: platelets.

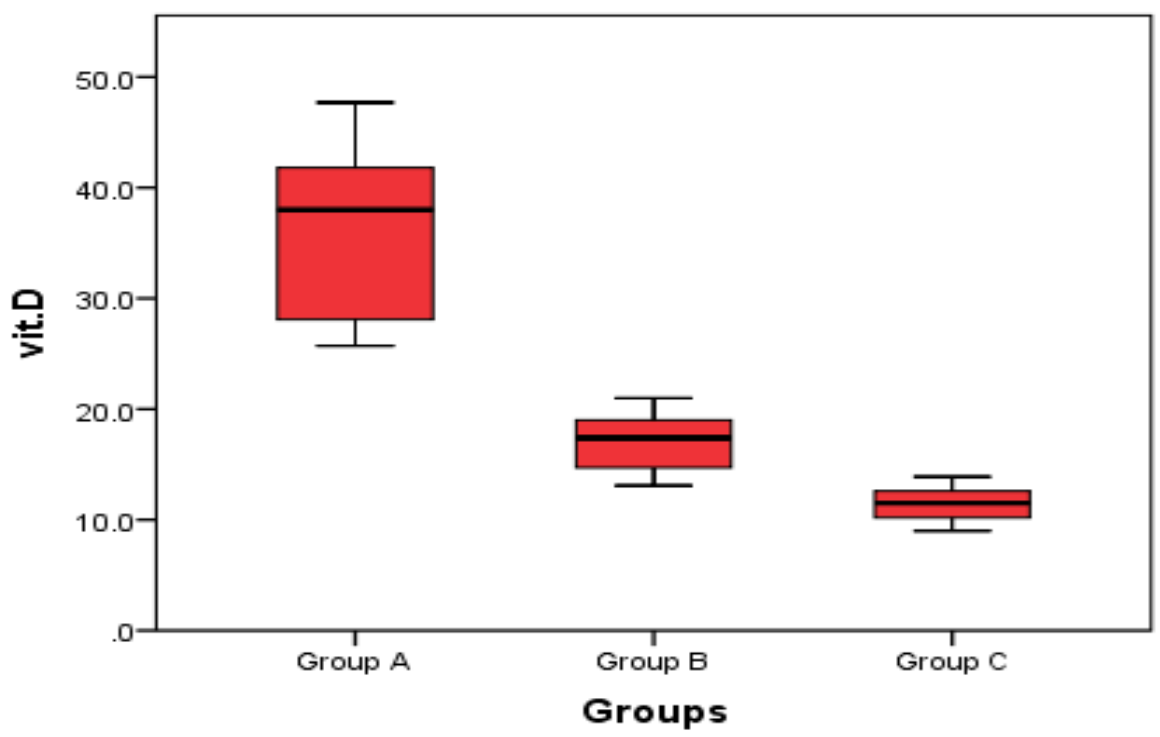

Figure 1: Comparison between groups regarding the level of vitamin D. 


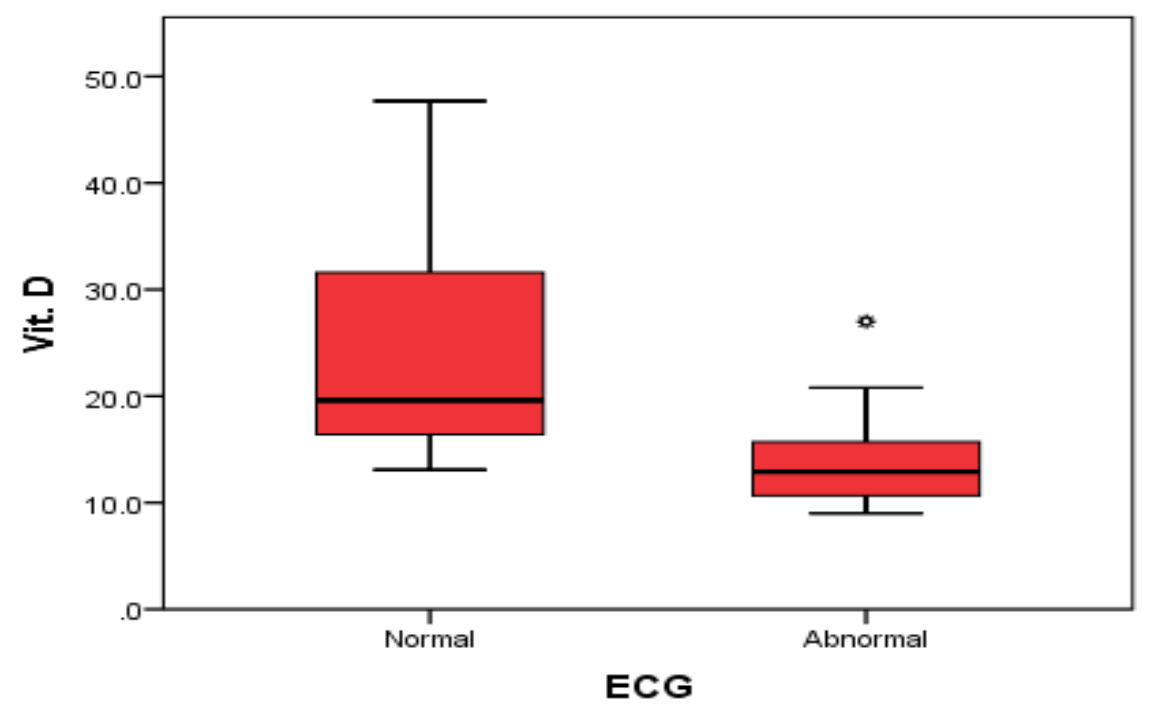

Figure 2: Comparison between patients with normal ECG and patients with abnormal ECG regarding the level of vitamin D.

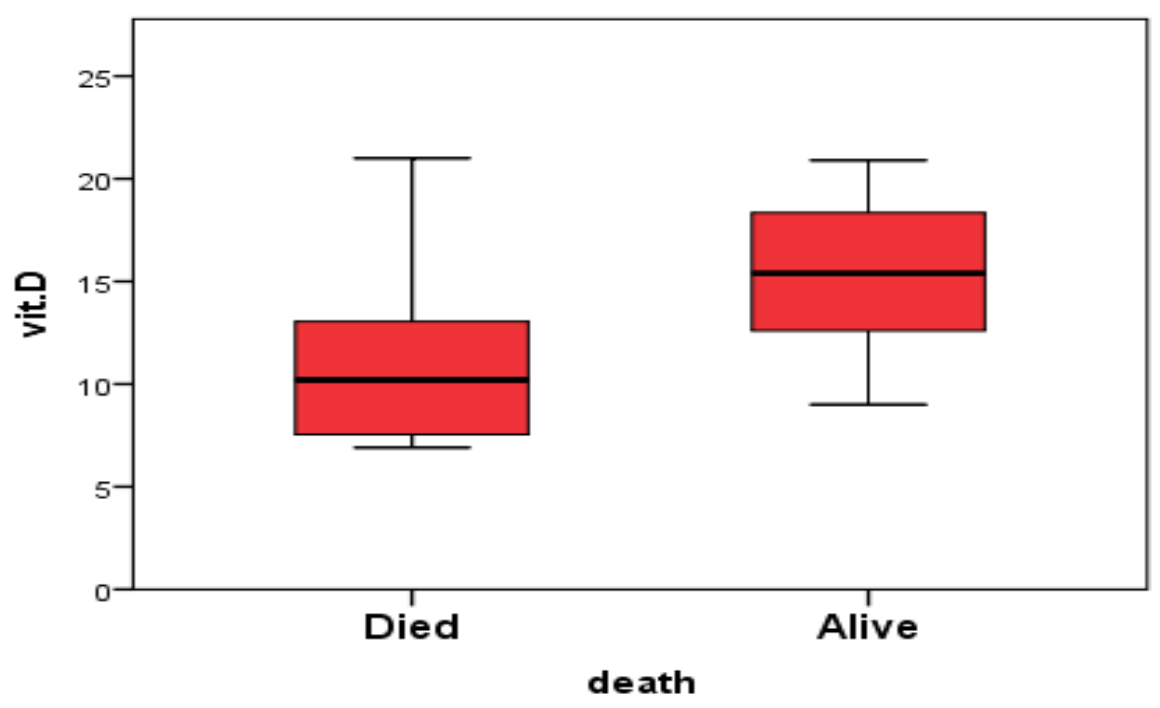

Figure 3: Comparison between alive and died patients regarding vitamin D level mm 


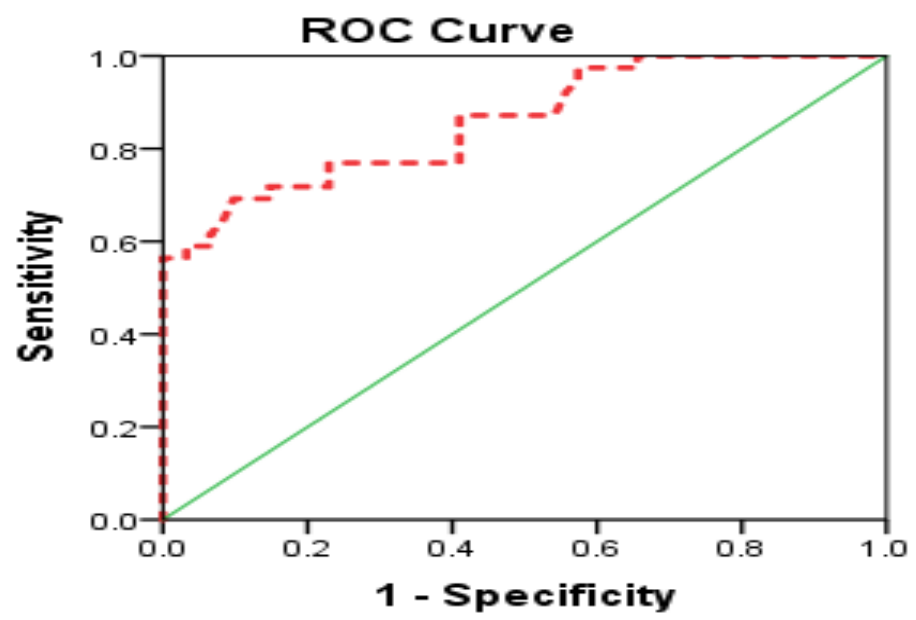

Figure 4: ROC curve of diagnostic performance of vitamin D to predict ECG abnormality

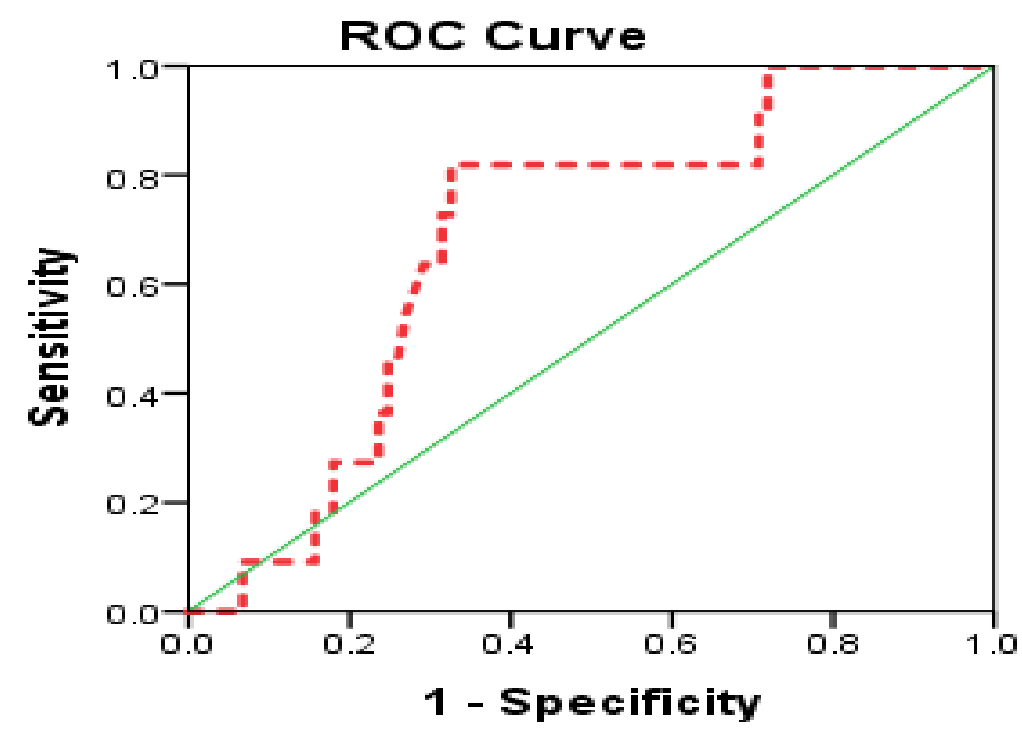

Figure 5: ROC curve of performance of vitamin D to predict mortality 


\section{Discussion}

In our study, Vitamin D was statistically higher in group A $(36 \pm 7.4)$ than group B (17 \pm 2.5$)$, and group C (11.4 \pm 1.5$), \mathrm{p}<0.001$. And between group $\mathrm{B} \& \mathrm{C}, \mathrm{p}<0.001$. This was in agreement with (8), Comparison between cases and control regarding vitamin $\mathrm{D}$ level shows that the mean value of vitamin $\mathrm{D}$ in studied patients was 22.3 and its value in control group was 28. also in (9), the mean vit D level was $34.4 \mathrm{ng} / \mathrm{ml}$ in controls vs 16.6 in patients with CKD.

In our study, the mean $\mathrm{Hb}$ was $13.7 \pm 1.0 \mathrm{~g} / \mathrm{dL}$ in group $\mathrm{A}, 10.5 \pm 1 \mathrm{~g} / \mathrm{dL}$ in group $\mathrm{B}$, and $9.8 \pm 1.4 \mathrm{~g} / \mathrm{dL}$ in group $\mathrm{C}$, the mean platelets count was $291 \pm 4010^{3} / \mathrm{UL}$ in group $\mathrm{A}$, $168 \pm 3610^{3} / \mathrm{UL}$ in group $\mathrm{B}$, and $120 \pm 30$ $10^{3} / \mathrm{UL}$ in group $\mathrm{C}$, the mean TLC count was 7.2 \pm 2.3 in group A, 5.2 \pm 2.9 in group B, and $4.5 \pm 3.1$ in group $C$. The mean urea was $13.9 \pm 3.6$ in group $\mathrm{A}, 83.8 \pm 5.4$ in group $\mathrm{B}$, and $128.9 \pm 6.5$ in group $\mathrm{C}$, the mean creatinine was $0.7 \pm 0.1$ in group $A, 2.4 \pm 0.1$ in group B, and $4.4 \pm 0.4$ in group $C$. there was statistical difference between the 3 groups regarding the level of $\mathrm{Hb}$, Plt, TLC, blood urea, and serum creatinine. Also there was statistical difference between group B and group $\mathrm{C}$ regarding the same investigations.
This was in consistent with (10) study, Levels of hemoglobin, leukocytes, and platelets of chronic kidney disease patients undergoing hemodialysis in Surabaya, All patients had anemia with the average levels of $\mathrm{Hb}$ was $8.17 \mathrm{~g} / \mathrm{dL}$. Nineteen (32\%) patients had Hb levels of $<7 \mathrm{~g} / \mathrm{dL}, 21(35 \%)$ and $16(27 \%)$ patients had $\mathrm{Hb}$ levels in the range of 7.1$9 \mathrm{~g} / \mathrm{dL}$ and 9.1-11 $\mathrm{g} / \mathrm{dL}$ respectively, and only $4(7 \%)$ patients had $\mathrm{Hb}$ levels in $>11$ $\mathrm{g} / \mathrm{dL}$. There were two (3\%) patients who had leukopenia $54\left(\% \%^{\bullet}\right)$ patients had normal range, and 4 (7\%) patients had leukocytosis. The average level of leukocyte was 6.79 $1 .{ }^{3} /$ UL. Based on leukocyte profile, $15 \%$ patients had normal neutrophil levels, $43 \%$ patients had normal lymphocyte levels, $22 \%$ had eosinophils higher than normal and $37 \%$ had basophils above normal. There were $22(37 \%)$ patients who had thrombocytopenia, $36(60 \%)$ patients were in normal range and $2(3 \%)$ patients had thrombocytosis. Platelet levels have an inverse correlation to the duration of HD. The average platelet level was $185.9310^{3} / \mathrm{UL}$.

Our results also agreed with (11), hemoglobin levels were below $10 \mathrm{gm} / \mathrm{dl}$ in $96 \%$ of the patients. And this also agreed with (12), who 
found that $21(70 \%)$ patients had moderate anemia and nine (30) had severe anemia.

It is well established that anemia develops in the course of chronic renal disease and is nearly universal in patients with ESRD. Lower hemoglobin levels may result from a loss of erythropoietin synthesis by the kidneys and/or the presence of inhibitors of erythropoietin synthesis, loss of small amount of blood during each hemodialysis (13).

In our study, PTH was statistically lower in group A than group B, and group $\mathrm{C}, \mathrm{p}<0.001$. While there was no significant difference between group $\mathrm{B} \& \mathrm{C}, \mathrm{p}=0.133$. Po4 was statistically lower in group A $(4 \pm 0.3)$ than group B (4.8 \pm 0.7$)$, and group C $(5 \pm 0.7)$, $\mathrm{p}<0.001$. While there was no significant difference between group $\mathrm{B} \& \mathrm{C}, \mathrm{p}=0.25$. Serum K was statistically lower in group A (4.4 \pm 0.5$)$ than group B $(5.5 \pm 0.5)$, and group C $(6.1 \pm 1), p<0.001$. And between group $\mathrm{B} \& \mathrm{C}, \mathrm{p}<0.001$.

Similarly, in (14), found that the mean Po4 in CKD patients was $5.1 \pm 1.3 \mathrm{mg} / \mathrm{dl}$ in, the mean IPTH was $270.2 \pm 249.5 \mathrm{pg} / \mathrm{ml}$, and this was consistent with (9), who found that the mean PTH in controls was 33.8 vs 538 in CKD patients, $\mathrm{p}<0.001$, and the mean Po4 was 3.5 in controls and 4.6 in CKD patients, $\mathrm{p}<0.001$.
In our study, Total Ca was statistically higher in group A $(9.5 \pm 0.5)$ than group B $(8.4 \pm 1)$, and group $\mathrm{C}(8 \pm 0.9), \mathrm{p}<0.001$. And between group $\mathrm{B} \& \mathrm{C}, \mathrm{p}=0.035$. this results were comparable with (9), the mean serum $\mathrm{Ca}$ was 9.5 in controls vs 8.65 in CKD patients, $\mathrm{p}<0.001$.

In this study, the group with normal ECG had statistically higher levels of vitamin D $($ mean $=24.5 \pm 10.8)$ compared to the group with abnormal ECG (mean= 13.9 \pm 4.1$)$, $\mathrm{p}<0.001$.

This was in consistent with (15), who found that the prevalence of major ECG abnormalities across 25-OH vitamin D sufficiency, insufficiency, and deficiency was $5.86 \%, 11 \%$, and $13.01 \%$, respectively $(P=0.01)$. Serum 25-OH vitamin D levels were a significant predictor of major ECG abnormalities after adjusting for possible confounders in the entire study data (continuous variable odds ratio [OR]: 0.98, 95\% confidence interval [CI]: 0.97$0.99, P=0.007$; categorical variable OR: 2.36, 95\% CI: $1.1-5.12, P=0.03)$ and in individuals without LVH (continuous variable OR: $0.98,95 \%$ CI: 0.96-0.99, $\mathrm{P}=0.004$; categorical variable OR: 2.97, 95\% CI: 1.1$8.08, P=0.03$ ) 
Our findings are consistent with (16), who reported that vitamin $\mathrm{D}$ exerts biphasic effect on cardiac function according to its serum levels. Reduced vitamin D $(<20 \mathrm{ng} / \mathrm{ml})$ appears to be associated with worse left ventricular thickness and mass which seems to be linked eventually to worse systolic functions in terms of end systolic volume and end systolic dimension. Higher vitamin D levels $(\geqslant 20 \mathrm{ng} / \mathrm{ml})$, however, seem to be linked to worse $\mathrm{LV}$ diastolic functions in terms of lower $e^{\prime}$, higher $E / e^{\prime}$ and longer IVRT. Also previous cross-sectional study by (17), showed that vitamin D deficiency associated with worse LV function.

Hypovitaminosis D $(<30 \mathrm{mg} / \mathrm{mL})$ has been shown to be associated with increased risk of cardiovascular disease and its risk factors i.e obesity, hypertension and diabetes, this was consistent was (18). While wasn't consistent with (19), who reported that vit D less than 20 $\mathrm{mg} / \mathrm{mL}$, could predict cardiovascular abnormalities.

The association of vitamin D therapy with allcause mortality was assessed in previous studies (20-22), they reported a significant inverse association between receiving vitamin $\mathrm{D}$ and the risk of death. The pooled result showed that receiving vitamin $\mathrm{D}$ was significantly associated with a $27 \%$ relative risk reduction of all-cause mortality (relative risk 0.73, 95\% CI 0.65-0.82). (23)

\section{Conclusion}

High prevalence of vit $\mathrm{D}$ deficiency in $\mathrm{CKD}$ patients, and showed a significant association between $25-\mathrm{OH}$ vitamin $\mathrm{D}$ levels and major ECG abnormalities and Echo.

\section{References}

1. Kaur G, Singh J, Kumar J. Vitamin D and cardiovascular disease in chronic kidney disease. Pediatr Nephrol. 2019;34(12):2509-22.

2. Lugg ST, Howells PA, Thickett DR. Optimal vitamin D supplementation levels for cardiovascular disease protection. Dis Markers. $2015 ; 2015$.

3. Russa D La, Pellegrino D, Montesanto A, Gigliotti P, Perri A, Russa A La, et al. Oxidative balance and inflammation in hemodialysis patients: biomarkers of cardiovascular risk? Oxid Med Cell Longev. 2019;2019.

4. Gluba-Brzózka A, Franczyk B, Ciałkowska-Rysz A, Olszewski R, Rysz J. Impact of vitamin D on the cardiovascular system in advanced chronic kidney disease (CKD) and dialysis patients. Nutrients. 2018;10(6):709.

5. Drüeke TB. Hyperparathyroidism in chronic kidney disease. In: Endotext [Internet]. MDText. com, Inc.; 2018.

6. Fondjo LA, Owiredu WKBA, Sakyi SA, Laing EF, Adotey-Kwofie MA, Antoh EO, et al. Vitamin D status and its association with insulin resistance among type 2 diabetics: A case-control study in Ghana. PLoS One. 2017;12(4):e0175388.

7. Al Mheid I, Patel RS, Tangpricha V, Quyyumi AA. Vitamin D and cardiovascular disease: is the evidence solid? Eur Heart J. 2013;34(48):3691-8. 
8. El-Arbagy AR, El-Zorkany KMA, Helwa MA, El-Khalifa EAM. Assessment of vitamin D in hemodialysis patients. Menoufia Med J. 2020;33(1):122.

9. Ammar YA, Nienaa YA, El-Banawy SS, Moghazy TF, Kandil NS, El-Sayed AA. Association of vitamin D deficiency with renal anemia and erythropoietin hyporesponsiveness in hemodialysis patients. J Egypt Soc Nephrol Transplant. 2017;17(4):125.

10. Kahdina M, Mardiana N, Fauziah D. Levels of Hemoglobin, Leukocytes, and Platelets of Chronic Kidney Disease Patients Undergoing Hemodialysis in Surabaya. Biomol Heal Sci J. 2018;1(1):29-33.

11. Chaudhari ST, Sadavarte A V, Chafekar D. Clinical profile of end stage renal disease in patients undergoing hemodialysis. MVP J Med Sci. 2017;4(1):8-13.

12. Aldwilla ZAHM, Sobh MA, Thabet AF. Renal anemia refractory to erythropoietin. J Curr Med Res Pract. 2020;5(2):146.

13. Stauffer ME, Fan T. Prevalence of anemia in chronic kidney disease in the United States. PLoS One. 2014;9(1):e84943.

14. Janmaat CJ, Van Diepen M, Gasparini A, Evans M, Qureshi AR, Ärnlöv J, et al. Lower serum calcium is independently associated with CKD progression. Sci Rep. 2018;8(1):1-9.

15. Tuliani TA, Shenoy M, Deshmukh A, Rathod A, Pant S, Badheka AO, et al. Major electrocardiographic abnormalities and 25hydroxy vitamin D deficiency: insights from National Health and Nutrition Examination Survey-III. Clin Cardiol. 2014;37(11):660-6.

16. Rahman MAA, Galal H, Omar AMS. Correlation between serum vitamin D level and cardiac function: Echocardiographic assessment. Egypt
Hear J. 2015;67(4):299-305.

17. Matias PJ, Ferreira C, Jorge C, Borges M, Aires I, Amaral T, et al. 25-Hydroxyvitamin D3, arterial calcifications and cardiovascular risk markers in haemodialysis patients. Nephrol Dial Transplant. 2009;24(2):611-8.

18. Martins D, Wolf M, Pan D, Zadshir A, Tareen N, Thadhani R, et al. Prevalence of cardiovascular risk factors and the serum levels of 25hydroxyvitamin D in the United States: data from the Third National Health and Nutrition Examination Survey. Arch Intern Med. 2007;167(11):1159-65.

19. Holick MF. Sunlight and vitamin D for bone health and prevention of autoimmune diseases, cancers, and cardiovascular disease. Am J Clin Nutr. 2004;80(6):1678S-1688S.

20. Jean G, Lataillade D, Genet L, Legrand E, Kuentz F, Moreau-Gaudry X, et al. Impact of hypovitaminosis $\mathrm{D}$ and alfacalcidol therapy on survival of hemodialysis patients: results from the French ARNOS study. Nephron Clin Pract. 2011;118(2):c204-10.

21. Sugiura S, Inaguma D, Kitagawa A, Murata M, Kamimura Y, Sendo S, et al. Administration of alfacalcidol for patients with predialysis chronic kidney disease may reduce cardiovascular disease events. Clin Exp Nephrol. 2010;14(1):43-50.

22. Shoben AB, Rudser KD, De Boer IH, Young B, Kestenbaum B. Association of oral calcitriol with improved survival in nondialyzed CKD. J Am Soc Nephrol. 2008;19(8):1613-9.

23. Duranton F, Rodriguez-Ortiz ME, Duny Y, Rodriguez M, Daurès J-P, Argilés A. Vitamin D treatment and mortality in chronic kidney disease: a systematic review and meta-analysis. Am J Nephrol. 2013;37(3):239-48.

To cite this article: Mohamed T. Ibrahim, Kamal M. Okasha, Ashraf Talaat, Amany G. Abd ElAziz, Ahmed E. Mansour. Evaluation of the Role of Vitamin D in Chronic Kidney Disease, Dialysis Patients and Its Impact on Cardio Vascular Mortality. BMFJ 2021; 38(3): 937-950. DOI: 10.21608/bmfj.2021.71835.1407 